\title{
Giant villous adenoma of rectum- what is the malignant potential and what is the optimal treatment? A case and review of literature
}

\author{
Lovenish Bains $^{1 *}$ (D), Pawanindra Lal ${ }^{1}$, Anubhav Vindal ${ }^{1}$ and Meeta Singh ${ }^{2}$
}

\begin{abstract}
Introduction: Villous adenomas are dubiously benign lesions, which are difficult to interpret because of their malignant potential. Distal villous adenomas present with bleeding or mucus discharge. Giant adenomas are not amenable for endoscopic or transanal resection. Only few isolated cases have been reported by laparoscopic resection. We present our case of a circumferential giant villous adenoma of the rectum managed successfully by laparoscopic ultra-low anterior resection with colo-anal anastomosis with a review of literature in regard to their malignant potential.
\end{abstract}

Case report: A 62-year-old lady presented with complaints of painless bleeding per rectum and a fleshy mass protruding from the anal canal which on digital rectal examination appeared a large soft velvety flat mass with mucus discharge. Colonoscopy showed circumferential irregular, friable, edematous mucosa in rectum extending for $15 \mathrm{~cm}$. Computed tomography showed a large heterogeneously enhancing polypoid mass lesion in the rectal wall involving the entire rectum. The patient underwent laparoscopic low anterior resection with colo-anal anastomosis and protecting loop ileostomy. Histopathological examination of the resected specimen revealed villous adenoma of the rectum with moderate to severe dysplasia.

Discussion: Villous adenomas are sessile growths lined by dysplastic glandular epithelium, whose risk of malignancy is especially high up to $50 \%$ when greater than $2 \mathrm{~cm}$ in size. Large size, villous content, and distal location are all associated with severe dysplasia in colorectal adenomas. Large villous rectal tumors, particularly of circumferential type pose a great challenge for endoscopic or transanal removal. Henceforth, open or laparoscopic surgery is required for these cases.

Conclusion: Giant rectal villous polyps are usually unresectable by endoscopic methods or transanal endoscopic microsurgery and are associated with a high rate of unsuspected cancer which requires a formal radical oncologic resection. As per current data, the combined risk of dysplasia/malignancy is about $83 \%$ with $50 \%$ risk of dysplasia and frank malignancy in 33\% of cases of giant rectal villous adenomas of more than $8 \mathrm{~cm}$ in size. Laparoscopic colorectal resection is safe and effective.

Keywords: Villous, Adenoma, Giant, Rectal, Malignant, Colorectal carcinoma, Laparoscopic, Colo-anal

\footnotetext{
* Correspondence: lovenishbains@gmail.com

'Department of Surgery, Maulana Azad Medical College, New Delhi, India

Full list of author information is available at the end of the article
}

(c) The Author(s). 2019 Open Access This article is distributed under the terms of the Creative Commons Attribution 4.0 International License (http://creativecommons.org/licenses/by/4.0/), which permits unrestricted use, distribution, and reproduction in any medium, provided you give appropriate credit to the original author(s) and the source, provide a link to the Creative Commons license, and indicate if changes were made. The Creative Commons Public Domain Dedication waiver (http://creativecommons.org/publicdomain/zero/1.0/) applies to the data made available in this article, unless otherwise stated. 


\section{Introduction}

The prevalence of adenomatous polyps of the colon and rectum was reported in approximately $25 \%$ of the population aged over 50 years [1]. A recent meta-analysis puts the pooled prevalence in average-risk individuals of adenomas, colorectal cancer, non-advanced adenomas, and advanced adenomas at $30.2 \%, 0.3 \%, 17.7 \%$, and $5.7 \%$, respectively [2]. The larger villous adenomas with severe dysplasia are mostly concentrated in the distal colon (left colon and rectum), in particular in the descending-sigmoid part [3]. As giant adenomas are difficult for endoscopic removal and malignant potential is not known, laparoscopic colectomy offers safe and effective management of these lesions with the benefits of accelerated postoperative recovery [4]. We present a case of a circumferential giant villous adenoma of the rectum managed successfully by laparoscopic ultra-low anterior resection with colo-anal anastomosis and review of literature in terms of malignant potential and optimal treatment of such tumors.

\section{Case summary}

A 62-year-old lady presented to our outpatient department with complaints of painless bleeding per rectum from 8 months and a fleshy mass protruding from the anal canal from 3 months. The mass was reducible on manual palpation and associated with profuse mucus discharge. The hydration status of the patient was adequate, she had mild pallor and abdominal examination was essentially normal. On digital rectal examination, a soft velvety flat mass was appreciated about $3 \mathrm{~cm}$ from anal verge extending from 9 o' clock to 5 o' clock along with mucus discharge. The upper extent of the lesion could not be reached. The laboratory investigations revealed hemoglobin $8.3 \mathrm{~g} \%$, normal electrolytes with no other abnormalities; carcinoembryonic antigen (CEA) was also within normal range. Initial biopsy revealed villous adenoma with focal moderate dysplasia. A colonoscopy was done which showed irregular, friable, edematous mucosa in rectum extending for $15 \mathrm{~cm}$ nearly circumferentially with no other lesions in the entire colon. Contrastenhanced computed tomography showed a large heterogeneously enhancing polypoid mass lesion in the rectal wall (max thickness $2.5 \mathrm{~cm}$ ) involving the entire rectum (Figs. 1 and 2). Surrounding fat planes were normal and there were no enlarged lymph nodes.

In view of the large size of the lesion with associated moderate dysplasia, a decision was made to perform a laparoscopic low anterior resection. The rectum and sigmoid colon were mobilized with high ligation of the inferior mesenteric artery, total mesorectal excision with circumferential radial margin up to the dentate line and divided beyond the lesion. Colo-anal anastomosis was performed using PROXIMATE ${ }^{\bullet}$ ILS curved intraluminal stapler

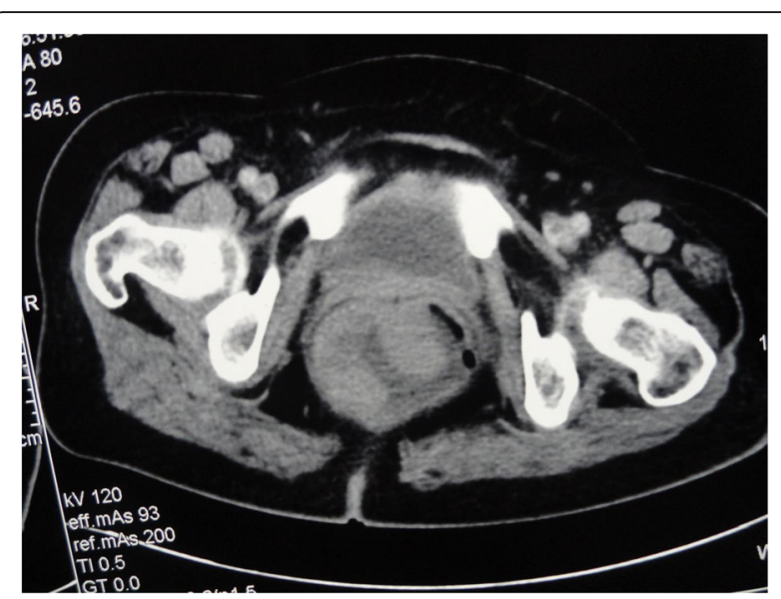

Fig. 1 CECT (transverse section) showing the tumor almost involving entire circumference of rectum

(25 mm) (Ethicon, Johnson, and Johnson, Cincinnati, $\mathrm{OH}, \mathrm{USA}$ ) and protected by a proximal loop ileostomy. The patient recovered well and was discharged on the fourth post-op day. At the time of discharge, digital rectal examination revealed a preserved anal sphincter tone and no troublesome mucus discharge.

On examination of the specimen, the lesion was seen to measure $16 \times 12 \mathrm{~cm}$, involving almost whole circumference with a $20 \mathrm{~cm}$ proximal and $1 \mathrm{~cm}$ distal margin (Fig. 3). Histopathological examination of the resected specimen revealed villous adenoma of the rectum with moderate to severe dysplasia (Figs. 4 and $5)$. Both the resected ends were free of tumor. Fourteen lymph nodes were isolated, all of which showed reactive changes. The patient underwent restoration of bowel continuity after 5 months and is healthy up to 1 year of follow-up.

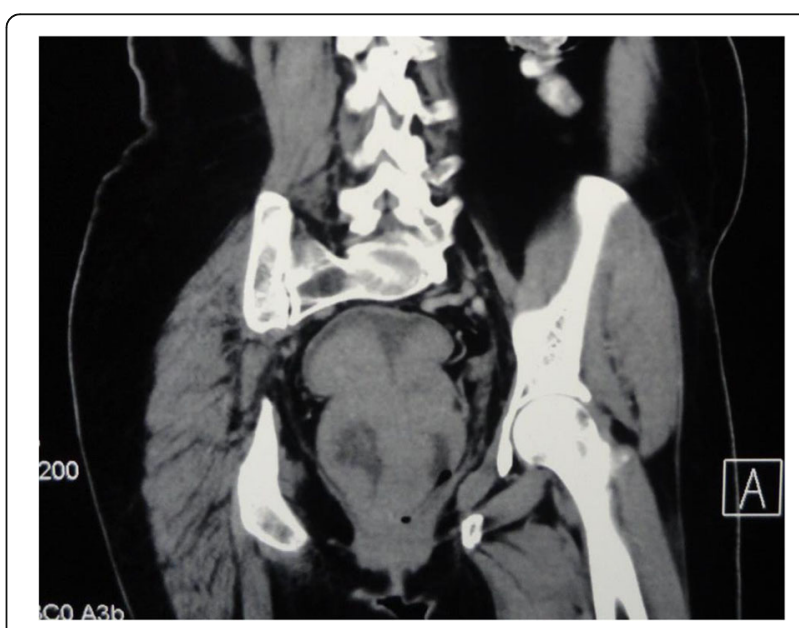

Fig. 2 CECT (coronal section) showing the tumour length 


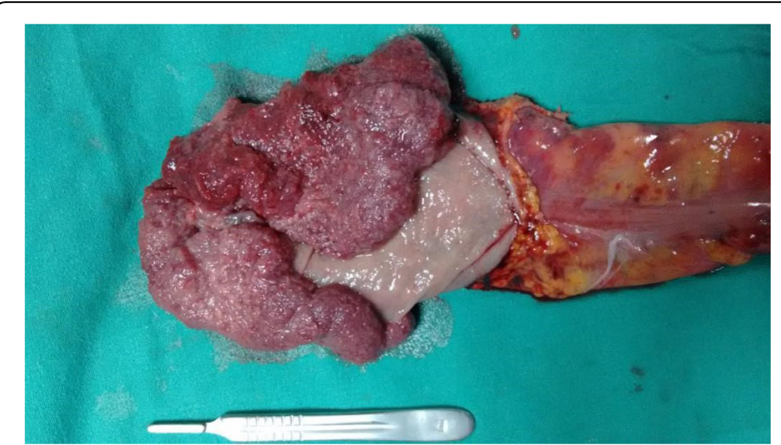

Fig. 3 Resected specimen (everted) showing the villous tumor, circumferential

\section{Discussion}

The natural history of colorectal carcinomas has been extensively studied in correlation with the underlying accumulation of genetic alterations as understood by the adenoma-carcinoma sequence. Adenomas are precursor lesions defined by the presence of intraepithelial neoplasia, characterized by varying degrees of nuclear stratification and loss of polarity. Polyps develop as mucosal excrescence as a consequence of accelerated crypt fission resulting from APC gene mutation [5].

The 'villous tumor' of the rectosigmoid was first described by Que'nu and Landel in 1899 . They described very large broad-based rectal tumors associated with secretory diarrhea [6]. The age-related prevalence of colorectal adenoma is $21-28 \%$ in $50-59$ years old, increasing to $40-45 \%$ in $60-69$ years old and rising to $53-58 \%$ in people over the age of 70 [7]. Histologically, polyps are classified as neoplastic (adenomas) or non-neoplastic. Non-neoplastic polyps have no malignant potential and include hyperplastic polyps, hamartomas, lymphoid aggregates, and inflammatory polyps. Neoplastic polyps or adenomas have malignant potential and are classified according to the World Health Organization as tubular, tubulovillous, or villous adenomas,

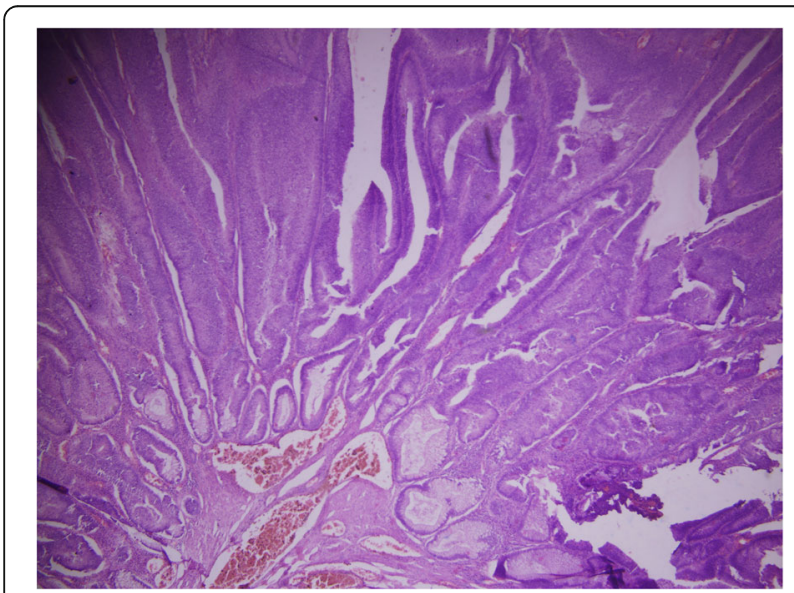

Fig. 4 Histopathology showing villous architecture, $\times 40, \mathrm{H} \& \mathrm{E}$

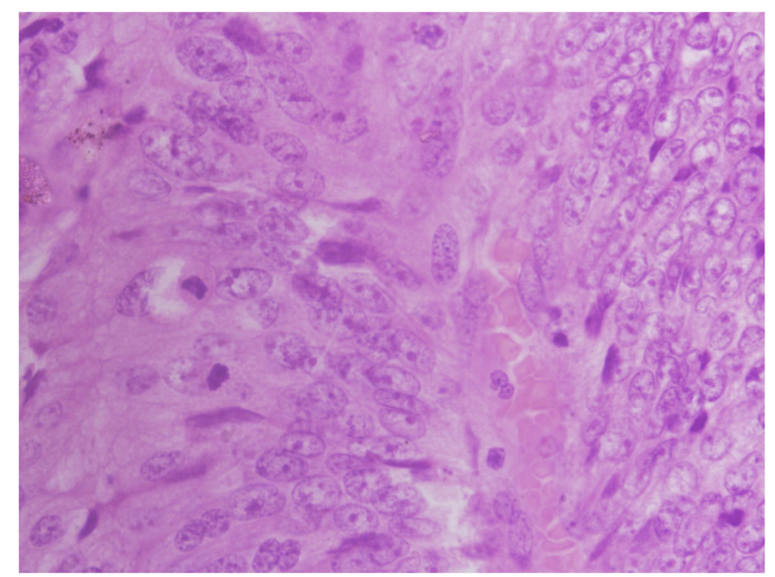

Fig. 5 Dysplasia as atypical mitotic figures, $\times 600, H \& E$

depending on the presence and volume of villous tissue [8]. Most of them $(70 \%$ to $85 \%)$ are classified as tubular $(<25 \%$ of villous tissue), $10-25 \%$ are tubulovillous $(25-75 \%$ of villous tissue), and $5 \%$ are villous adenomas $(75-100 \%$ of villous tissue) [8]. Villous adenomas are classically sessile with a velvety or hairy surface and microscopically leaf-like projections lined by dysplastic glandular epithelium. Villous architecture is defined arbitrarily by the length of the glands exceeding twice the thickness of normal colorectal mucosa [8,9].

Giant polyps are usually defined as more than $3 \mathrm{~cm}$ on endoscopy $[10,11]$; however, limited literature is available about optimal management of giant villous adenomas more than $10 \mathrm{~cm}[12,13]$. Our case is $16 \times 12 \mathrm{~cm}$ which was successfully managed with laparoscopic technique.

The risk of malignant degeneration is related to both the size and type of polyp $[2,9,10]$. Tubular adenomas are associated with malignancy in only $5 \%$ of cases, whereas villous adenomas may harbor cancer in up to $40 \%[2,10]$. Tubulovillous adenomas are at intermediate risk $(22 \%)$. There is less than a $5 \%$ incidence of carcinoma in an adenomatous polyp less than $1 \mathrm{~cm}$ in size, whereas there is a $50 \%$ chance that a villous adenoma greater than $2 \mathrm{~cm}$ in size will contain cancer $[10,11]$. The risk of malignancy is especially high when adenomas are large $(>10$ $\mathrm{mm}$ ) and multiple, with a villous pathology $[2,3,9]$. Not all neoplastic polyps evolve to cancer but most colorectal cancers originate as a polyp. This fact forms the basis for secondary prevention strategies to eliminate colorectal cancer by targeting the neoplastic polyps for removal before malignancy develops $[2,3]$.

A recent search on PubMed for keywords 'giant rectal villous adenoma' and 'giant rectal villous tumor' from 2005 to 2018 yielded 33 and 31 results respectively. The keyword 'malignant potential of rectal villous adenoma' yielded 24 results A total of 25 giant villous tumors 
(including our case) with size range 5-31 cm were reviewed which showed carcinoma (including invasive) in 8 , high-grade dysplasia in 6, low- to moderate-grade dysplasia in 6 whereas rest negative for malignancy (Table 1). It puts the risk of dysplasia to about $50 \%$ and malignancy in $33 \%$ of cases of giant rectal villous adenomas. This analysis suggests that endoscopically unresectable polyps or giant polyps of villous type are best treated by radical oncologic resection.

In a study that analyzed 7590 adenomatous polyps to determine risk factors for high-grade dysplasia or invasion, the size was the strongest predictor. The percent of adenomas with high-grade dysplasia or invasive cancer based on the size of the polyp was as follows: $<5 \mathrm{~mm}$, 3.4\%; 5-10 mm, 13.5\%; and > $10 \mathrm{~mm}, 38.5 \%$ [11]. Large size, villous content and distal location are all associated with severe dysplasia in colorectal adenomas [3, 8-10].
Most patients with adenomas are asymptomatic, especially when their neoplasm is identified by screening or surveillance $[2,7,9,10]$. Hematochezia and anemia are common presenting features due to bleeding from the tumor. Rectosigmoid lesions can present with protrusion of mass or tenesmus. Other symptoms include fever, malaise, weight loss, and abdominal pain. Villous rectal tumors may reach a large size, and look like a "rug" involving the entire rectum, without degenerating into malignant disease [6]. An important fact is that the giant villous adenomas may excrete large quantities of mucus and potassium, which can produce mucus diarrhea and electrolytic alterations. McKittrick-Wheelock syndrome, which is a disorder characterized by fluid and electrolyte depletion, is caused by a secretory colorectal tumor [32].

Colonoscopy is the procedure of choice for diagnosing colorectal polyps as it is the most accurate method for

Table 1. Giant villous tumor of rectum in recent literature with size and malignant potential

\begin{tabular}{|c|c|c|c|}
\hline $\begin{array}{l}\text { S } \\
\text { no. }\end{array}$ & Author & Size & Histopathology \\
\hline 1. & $\begin{array}{l}\text { Rickenbacher A, Bauerfeind P } \\
\text { et al. [12] }\end{array}$ & $\begin{array}{l}\text { 1. } 15 \mathrm{~cm} \\
\text { 2. }- \\
\text { 3. } 8 \mathrm{~cm}\end{array}$ & $\begin{array}{l}\text {-Low-grade dysplasia } \\
\text {-High-grade dysplasia } \\
\text {-Giant tubulovillous adenoma with a small focus of invasive carcinoma }\end{array}$ \\
\hline 2. & $\begin{array}{l}\text { Durán-Martínez M, Medina-Fernández } \\
\text { FJ et al. [13] }\end{array}$ & $10 \times 8 \times 4 \mathrm{~cm}$ & Giant villous adenoma high-grade dysplasia \\
\hline 3. & $\begin{array}{l}\text { van der Pool AEM, de Graaf EJR } \\
\text { et al. [14] }\end{array}$ & $\begin{array}{l}\text { 1. } 12 \mathrm{~cm} \\
\text { 2. } 24 \mathrm{~cm}^{2} \\
\text { 3. } 5-14 \mathrm{~cm} \text { or } 99 \\
\mathrm{~cm}^{2}\end{array}$ & $\begin{array}{l}\text {-Villous adenoma } \\
\text {-Villous adenoma with high-grade dysplasia and intramucosal carcinoma } \\
\text {-Villous adenoma with low-grade dysplasia }\end{array}$ \\
\hline 4. & Agnes A, Novelli D et al. [15] & $9 \mathrm{~cm}$ & $\begin{array}{l}\text { Villous adenoma with areas of intramucosal adenocarcinoma and } \\
\text { high-grade dysplasia }\end{array}$ \\
\hline 5. & Challis BG, Lim CT et al. [16] & $10 \mathrm{~cm}$ & Tubulovillous adenoma exhibiting moderate to low-grade dysplasia \\
\hline 6. & Okano M, Okuyama M et al. [17] & $10 \mathrm{~cm}$ & \\
\hline 7. & Mois El, Graur F et al. [18] & $14 \mathrm{~cm}$ & Low-grade dysplasia with focal high-grade dysplasia \\
\hline 8. & Nakhla SG, Murakami TT et al. [19] & $17 \mathrm{~cm}$ & $\begin{array}{l}\text { Large rectal villous adenoma coexistent with a poorly differentiated } \\
\text { neuroendocrine tumor of the rectum }\end{array}$ \\
\hline 9. & Kure K, Kawai M et al. [20] & $12.7 \times 11.5 \mathrm{~cm}$ & $\begin{array}{l}\text { Mostly tubulovillous adenoma, but partially moderately differentiated } \\
\text { adenocarcinoma. }\end{array}$ \\
\hline 10. & Das P, Vijay MK et al. [21] & $8.5 \times 6 \times 4 \mathrm{~cm}$ & Giant villous adenoma with low-grade dysplasia \\
\hline 11. & Ohtsuka M, Hata T et al. [22] & & Concurrent adenocarcinoma \\
\hline 12. & Roriz-Silva R, Andrade AA et al. [23] & $14 \mathrm{~cm}$ & Villous adenoma with low-grade atypia \\
\hline 13. & $\begin{array}{l}\text { Aboul Hosn M, Abdel-Hafiez N } \\
\text { et al. [24] }\end{array}$ & $12 \mathrm{~cm}$ & No evidence of invasive carcinoma \\
\hline 14. & $\begin{array}{l}\text { Barendse RM, van den Brandt S } \\
\text { et al. [25] }\end{array}$ & $9 \mathrm{~cm}$ & Villous adenoma with focal high-grade dysplasia \\
\hline 15. & Choi WH, Ryuk J et al. [26] & $25 \mathrm{~cm} \times 12 \mathrm{~cm}$ & Well-differentiated adenocarcinomas arising in villotubular adenomas \\
\hline 16. & Tuță LA, Boşoteanu M et al. [27] & $12 \times 10 \mathrm{~cm}$ & Well-differentiated adenocarcinoma arising within a villous adenoma. \\
\hline 17. & Dagan A and Reissman P [28]. & $31 \mathrm{~cm}$ & Low- to high-grade dysplasia \\
\hline 18. & Cubuk R, Tasali N et al. [29] & $17 \times 9 \mathrm{~cm}$ & Villous adenoma without high-grade dysplasia \\
\hline 19. & Koning GG, Rensma PL et al. [30] & $15 \times 8$ & Low-grade dysplasia \\
\hline 20. & Nagri S, Eskaros S et al. [31] & $8 \times 5 \times 4 \mathrm{~cm}$ & Giant villous adenoma with high-grade dysplasia \\
\hline 21. & Bains L, Lal P et al. (current case) & $16 \times 12 \mathrm{~cm}$ & Giant villous adenoma of the rectum with moderate to severe dysplasia \\
\hline
\end{tabular}


detecting polyps of all sizes, and it allows biopsy of lesions and resection of most polyps [2, 33, 34]. Endoscopic polypectomy is the mainstay of polyp management because the majority of lesions are protuberant. Polyp size, position, and access can make this very taxing and a great challenge for endoscopic or transanal endoscopic microsurgery (TEMS) removal. Large villous tumors of the low and mid rectum can be treated by per-anal resection with recurrence rates equivalent to transanal endoscopic microsurgery; however, the mean length of the tumor was $5.2 \mathrm{~cm}$ in this series [35]. TEMS can be employed in lesions up to $6 \mathrm{~cm}$ in carefully selected patients but owing to giant size, location, circumferential, and diffuse villous lesion, it has not been indicated for such lesions. Such big lesions may approach the dentate line and pose an increased risk of perforation with serious complications. Another unfavorable point of endoscopic resection of circumferential rug like mucosa is the development of stricture [36-39].

Carditello et al. treated 104 villous tumors of the rectum with a mean size of $3 \mathrm{~cm}$ surgically by local or wide excision. The malignant potential of the tumors was $30 \%$, including $10 \%$ invasive malignancy and recurrence rate was 24 after a mean follow up of 6.5 years [40]. A recent study found that the incidence of cancer in patients undergoing colectomy for an irretrievable polyp is $17.7 \%$ [39]. Open or laparoscopic colorectal resection is the procedure of choice for lesions not eligible for endoscopic resection and for large sessile villous tumors [4, $23,26,39$ ]. It has been demonstrated a mortality rate of $0.3 \%$ with an anastomotic leak rate of $1.4 \%[4,11,39]$. Complete excision is warranted for rectal villous adenomas, as biopsies were accurate only $50 \%$ of the time, and 1 in 8 patients had unsuspected cancer found after excision $[35,37,41]$.

\section{Conclusion}

Giant villous adenoma is a high-grade dysplastic lesion with conversion rate from adenoma to carcinoma approaching $17-33 \%$. Troublesome mucus discharge and bleeding may result in severe hemodynamic alterations. As per current data, the combined risk of dysplasia/malignancy is about $83 \%$ with $50 \%$ risk of dysplasia and frank malignancy in $33 \%$ of cases of giant rectal villous adenomas of more than $8 \mathrm{~cm}$ in size. Giant rectal villous polyps are usually unresectable by endoscopic methods or transanal endoscopic microsurgery and are associated with a high rate of unsuspected cancer which requires a formal radical oncologic resection. Laparoscopic colorectal resection is safe and effective.

\section{Acknowledgements}

We thank the contribution of Dr. Daljit Kaur and Varinder Singh in the preparation of this manuscript.

\section{Authors' contributions}

$L B$ conceived the concept. $L B, P L$, and $A V$ are responsible for the design. $L B$ and $P L$ are responsible for the definition of intellectual content. $L B$ and $P L$ are responsible for the literature search. $L B$ and $P L$ are responsible for data acquisition and analysis. LB and PL prepared the manuscript and are responsible for manuscript editing. MS provided the histopathological diagnosis. LB, PL, and AV reviewed the manuscript. All authors read and approved the final manuscript.

Funding

Nil

Availability of data and materials

The data supporting the conclusions of this article are included in the article.

\section{Ethics approval and consent to participate}

This manuscript has been approved by our Departmental Review Board.

\section{Consent for publication}

Written informed consent was obtained from the patient for publication of this manuscript and any accompanying images. A copy of the written consent is available for review by the Editor-in-Chief of this journal.

\section{Competing interests}

The authors declare that they have no competing interests.

\section{Author details}

1Department of Surgery, Maulana Azad Medical College, New Delhi, India.

2Department of Pathology, Maulana Azad Medical College, New Delhi, India.

Received: 17 April 2019 Accepted: 19 June 2019

Published online: 25 June 2019

\section{References}

1. Giacosa A, Frascio F, Munizzi F. Epidemiology of colorectal polyps. Tech Coloproctol. 2004;8(Suppl 2):s243-7.

2. Heitman SJ, Ronksley PE, Hilsden RJ, Manns BJ, Rostom A, Hemmelgarn BR. Prevalence of adenomas and colorectal cancer in average risk individuals: a systematic review and meta-analysis. Clin Gastroenterol Hepatol. 2009;7(12): 1272-8.

3. Giuliani A, Caporale A, Corona M, Ricciardulli T, di Bari M, Demoro M, et al Large size, Villous content and Distal location are associated with severe dysplasia in colorectal adenomas. Anticancer Res. 2006;26:3717-22.

4. Pokala N, Delaney CP, Kiran RP, Brady K, Senagore AJ. Outcome of laparoscopic colectomy for polyps not suitable for endoscopic resection. Surg Endosc. 2007;21(3):400-3.

5. Polyak K, Hamilton SR, Vogelstein B, Kinzler KW. Early alteration of cell cycleregulated gene expression in colorectal neoplasia. Am J Pathol. 1996;149: 381-7.

6. Que'nu E, Landel G. Des tumeurs villeuses ou e'pithe'-liomas superficiels ve'ge'tants du rectum. Rev de Gynec et de Chi Abdom. 1899;3:95-126.

7. Williams AR, Balasooriya BA, Day DW. Polyps and cancer of the large bowel: a necropsy study in Liverpool. Gut. 1982;23:835-42.

8. Morson BC, Sobin LH. Histological typing of intestinal tumours. In International histological classification of tumours, No. 15. Geneva: World Health Organization; 1976.

9. Shussman N, Wexner SD. Colorectal polyps and polyposis syndromes. Gastroenterol Rep (Oxf). 2014:2(1):1-15.

10. O'Brien MJ, Winawer SJ, Zauber AG, Gottlieb LS, Sternberg SS, Diaz B, et al. The National Polyp Study. Patient and polyp characteristics associated with high-grade dysplasia in colorectal adenomas. Gastroenterology. 1990;98(2): 371-9.

11. Gschwantler M, Kriwanek S, Langner E, Göritzer B, Schrutka-Kölbl C,

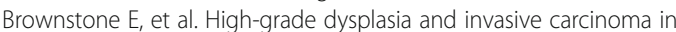
colorectal adenomas: a multivariate analysis of the impact of adenoma and patient characteristics. Eur J Gastroenterol Hepatol. 2002;14(2):183-8.

12. Rickenbacher A, Bauerfeind P, Rössler F, Turina M. Sequential endoscopic and surgical removal of giant rectal adenomas extending to the dentate line. Tech Coloproctol. 2018;22(5):379-81. https://doi.org/10.1007/s10151018-1794-1 Epub 2018 Jun 1 
13. Durán-Martínez M, Medina-Fernández FJ, Martínez-Dueñas JL, Díaz-López C, Briceño-Delgado J. Endoanal resection of a giant villous adenoma in the middle rectum—a video vignette. Colorectal Dis. 2018;20(4):357. https://doi. org/10.1111/codi.14032.

14. van der Pool AEM, de Graaf EJR, Vermaas M, Barendse RM, Doornebosch PG. McKittrick Wheelock syndrome treated by transanal minimally invasive surgery: a single-center experience and review of the literature. J Laparoendosc Adv Surg Tech A. 2018;28(2):204-8. https://doi.org/10.1089/ lap.2017.0195 Epub 2017 Jun 28.

15. Agnes A, Novelli D, Doglietto GB, Papa $\bigvee$. A case report of a giant rectal adenoma causing secretory diarrhea and acute renal failure: McKittrickWheelock syndrome. BMC Surg. 2016;16(1):39Published 2016 Jun 7. https:// doi.org/10.1186/s12893-016-0153-2.

16. Challis BG, Lim CT, Cluroe A, Cameron E, O'Rahilly S. The McKittrickWheelock syndrome: a rare cause of curable diabetes. Endocrinol Diabetes Metab Case Rep. 2016;2016:160013. https://doi.org/10.1530/EDM-16-0013.

17. Okano M, Okuyama M, Nishino M, Hoshino H, Kawada J, Kim Y, et al. A case of large rectal villous adenoma associated with tenesmus and body weight loss. Gan To Kagaku Ryoho. 2016;43(12):1748-50.

18. Mois El, Graur F, Sechel R, Al-Hajjar N. McKittrick-Wheelock syndrome: a rare case report of acute renal failure. Clujul Med. 2016;89(2):301-3. https://doi. org/10.15386/cjmed-536 Epub 2016 Apr 15.

19. Nakhla SG, Murakami $\Pi$, Sundararajan S. Poorly differentiated neuroendocrine tumor of the rectum coexistent with giant rectal villous adenoma presenting as McKittrick-Wheelock syndrome. Case Rep Oncol Med. 2015;2015:242760. https:/doi.org/10.1155/2015/242760 Epub 2015 Nov 22.

20. Kure K, Kawai M, Ishiyama S, Kamiyama H, Tomiki Y, Sakamoto K, et al. Complete endoscopic submucosal dissection of a giant rectal villous adenocarcinoma with electrolyte depletion syndrome. Case Rep Gastroenterol. 2015;9(2):126-31. https:// doi.org/10.1159/000382070.eCollection2015May-Aug.

21. Das P, Vijay MK, Yadav R, Kumar S, Sharma J, Gupta SD. Giant villous adenoma of rectum mimicking an infiltrating adenocarcinoma. Trop Gastroenterol. 2015;36(2):137-9.

22. Ohtsuka M, Hata T, Hiraki M, Takeyama H, Nonaka R, Uemura M, et al. A case of concurrent cancer in a giant rectal villous adenoma that resulted in extensive lymph node metastases. Gan To Kagaku Ryoho. 2015;42(6):747-50.

23. Roriz-Silva R, Andrade AA, Ivankovics IG. Giant rectal villous adenoma: surgical approach with rectal eversion and perianal coloanal anastomosis. Int J Surg Case Rep. 2013;5(2):97-9.

24. Aboul Hosn M, Abdel-Hafiez N, Abdel-Wahab R, Al-Ahmadie A, Antar A, Dbouk $\mathrm{H}$, et al. A giant rectal villous adenoma with a malicious intent. Gastrointest Cancer Res. 2013;6(5-6):144-9.

25. Barendse RM, van den Brandt S, Dekker E, Fockens P. McKittrick-Wheelock syndrome. Ned Tijdschr Geneeskd. 2013;157(3):A5567.

26. Choi WH, Ryuk J, Kim HJ, Park SY, Park JS, Kin GW, et al. A case of giant rectal villous tumor with severe fluid-electrolyte imbalance treated by laparoscopic low anterior resection. J Korean Surg Soc. 2012;82(5):325-9.

27. Tuță LA, Boşoteanu M, Deacu M, Dumitru E. McKittrick-Wheelock syndrome: a rare etiology of acute renal failure associated to well-differentiated adenocarcinoma (G1) arising within a villous adenoma. Rom J Morphol Embryol. 2011;52(3 Suppl):1153-6.

28. Dagan A, Reissman P. Giant secretory villous adenoma of the rectum and sigmoid presenting as McKittrick-Wheelock syndrome. Int J Colorectal Dis. 2010; 25(7):909-10. https://doi.org/10.1007/s00384-010-0893-x Epub 2010 Feb 18.

29. Cubuk R, Tasali N, Arslan G, Midi A, Manukyan MN, Guney S. A giant villous adenoma: case mimicking rectosigmoid malignancy; radiological survey to diagnosis. Prague Med Rep. 2010;111(1):76-81.

30. Koning GG, Rensma PL, van Milligen de Wit AW, van Laarhoven CJ. In-onecontinuity rectal excision and anal mucosectomy of a giant villous adenoma: an alternative surgical approach. Case Rep Gastroenterol. 2008; 2(2):175-80. Published 2008 May 24. https://doi.org/10.1159/000129705.

31. Nagri S, Eskaros S, Arya M, Arya Y, Anand S. Giant villous adenoma presenting as a mass protruding from the rectum in a 29-year-old female patient. Int J Colorectal Dis. 2007;22(12):1549. https://doi.org/10.1007/ s00384-006-0266-7 Epub 2007 Jan 23.

32. McKittrick LS, Wheelock FC. Carcinoma of the colon, 1954. Dis Colon Rectum. 1997;40(12):1494-5 discussion 1495-6.

33. Irvine EJ, O'Connor J, Frost RA, Shorvon P, Somers S, Stevenson GW, et al. Prospective comparison of double-contrast barium enema plus flexible sigmoidoscopy versus colonoscopy in rectal bleeding. Gut. 1988;29:1188-93.
34. Schrock TR. Colonoscopy versus barium enema in the diagnosis of colorectal cancer and polyps. Gastrointest Endosc Clin North Am. 1993; 3:585-610.

35. Featherstone JM, Grabham JA, Fozard JB. Per-anal excision of large, rectal, villous adenomas. Dis Colon Rectum. 2004;47(1):86-9 Epub 2004 Jan 2.

36. Binmoeller KF, Bohnacker S, Seifert H, Thonke F, Valdeyar H, Soehendra N. Endoscopic snare excision of "giant" colorectal polyps. Gastrointest Endosc. 1996;43(3):183-8.

37. Dell'Abate P, losca A, Galimberti A, Piccolo P, Soliani P, Foggi E. Endoscopic treatment of colorectal benign-appearing lesions $3 \mathrm{~cm}$ or larger: techniques and outcome. Dis Colon Rectum. 2001:44(1):112-8.

38. Cho SD, Herzig DO, Douthit MA, Deveney KE. Treatment strategies and outcomes for rectal villous adenoma from a single-center experience. Arch Surg. 2008;143(9):866-70.

39. Delaney CP, Brady K, Woconish D, Parmar SP, Champagne BJ. Towards optimizing perioperative colorectal care: outcomes for 1,000 consecutive laparoscopic colon procedures using enhanced recovery pathways. Am J Surg. 2012;203:353-5 discussion 5-6.

40. Carditello A, Milone A, Paparo D, Anastasi G, Mollo F, Stilo F. Tubulo-villous rectal tumours. Results of surgical resection in relation to histotype (30 years experience). Chir Ital. 2004;56(4):517-21.

41. Bertelson NL, Kalkbrenner KA, Merchea A, Dozois EJ, Landmann RG, De Petris $\mathrm{G}$, et al. Colectomy for endoscopically unresectable polyps: how often is it cancer? Dis Colon Rectum. 2012;55:1111-6.

\section{Publisher's Note}

Springer Nature remains neutral with regard to jurisdictional claims in published maps and institutional affiliations.
Ready to submit your research? Choose BMC and benefit from:

- fast, convenient online submission

- thorough peer review by experienced researchers in your field

- rapid publication on acceptance

- support for research data, including large and complex data types

- gold Open Access which fosters wider collaboration and increased citations

- maximum visibility for your research: over $100 \mathrm{M}$ website views per year

At BMC, research is always in progress.

Learn more biomedcentral.com/submissions 